\title{
Urdimento
}

Revista de Estudos em Artes Cênicas

E-ISSN: 2358.6958

\section{Teatro Aprisionado: trocando experiências artísticas em contextos carcerários}

\author{
Christina Gontijo Fornaciari \\ Magno Bucci \\ Vicente Concílio \\ Viviane Narvaes \\ Zeca Nosé \\ João Marcos Buch
}

\section{Para citar este artigo:}

FORNACIARI, Christina Gontijo; BUCCI, Magno; CONCILIO, Vicente; NARVAES, Viviane; NOSÉ, Zeca; BUCH, João Marcos. Teatro Aprisionado: trocando experiências artísticas em contextos carcerários. Urdimento, Florianópolis, v. 3, n. 39, nov./dez. 2020. 


\title{
Urdimento
}

\author{
Teatro Aprisionado: \\ Trocando experiências artísticas em contextos carcerários
}

\author{
Christina Gontijo Fornaciari \\ Magno Bucci \\ Vicente Concílio ${ }^{3}$ \\ Viviane Narvaes ${ }^{4}$ \\ Zeca Nosé5 \\ João Marcos Buch ${ }^{6}$
}

\begin{abstract}
Resumo
Transcrição da mesa Teatro Aprisionado: trocando experiências artísticas em contextos carcerários transmitida pela plataforma Youtube, em 25 de maio de 2020, em meio à Pandemia de Coronavírus. Participaram deste encontro os diretores teatrais Christina Fornaciari, Magno Bucci, Vicente Concilio, Viviane Narvaes e Zeca Nosé e o Juiz de Direito, João Marcos Buch.
\end{abstract}

Palavras-chave: Teatro na prisão. Sistema penitenciário. Direitos Humanos.

1 Profa. Dra. Adjunta da Universidade Federal de Viçosa/MG. Doutora em Artes Cênicas pela Universidade Federal da Bahia (2014). Mestra em Performance pela Queen Mary, University of London (2005) e em Teorias e Práticas Teatrais pela ECA/USP (2008). Graduada em Direito pela Faculdade Milton Campos (2002). christinafornaciari@gmail.com

2 Prof. Dr. FAAP/Ribeirão Preto e Coordenador dos grupos Mulheres de Atenas e Confraria da Serra, respectivamente na Penitenciária Feminina de Ribeirão Preto e Penitenciária de Serra Azul I. Graduado em Pedagogia pela Pontifícia Universidade Católica de São Paulo (1976). Mestre (1985) e Doutor (1994) em Artes Cênicas pela Universidade de São Paulo. magnobucci@yahoo.it

${ }^{3}$ Prof. Dr. Universidade Estadual de Santa Catarina. Licenciado, Mestre (2006) e Doutor (2013) em Artes Cênicas pela Universidade de São Paulo. Coordena o Coletivo de Teatro do Presídio Feminino de Florianópolis, que faz parte do programa de extensão Pedagogia do Teatro e Processos de Criação; e do grupo de pesquisa Infiltrações das artes cênicas nos espaços de privação de liberdade. viconcilio@gmail.com

${ }^{4}$ Profa. Dra. Universidade Federal do Estado do Rio de Janeiro (UFRJ). Doutora em Artes Cênicas pela Escola de Comunicações e Artes da USP. Coordena, em parceria com a professora Natália Ribeiro Fiche, o Programa de Extensão Cultura na Prisão. vivianenarvaes@gmail.com

${ }^{5}$ Prof. Ms. Universidade Federal do Amapá, Mestre em Teatro para Universidade Estadual de Santa Catarina (UDESC), Doutorando em Artes da Cena da Universidade Estadual de Campinas (UNICAMP), onde desenvolve a pesquisa O Teatro amador a partir de dois P(s): Putas e Presos. jfzecanose@gmail.com

6 Juiz de Direito da Vara de Execuções Penais da Comarca de Joinville/SC, Mestre em Hermenêutica Constitucional, Especialista em Política Criminal, formador da Escola Nacional de Formação e Aperfeiçoamento de Magistrados e escritor. 
Imprisioned Theater:

Exchanging artistic experiences in prison contexts

\begin{abstract}
This paper is a transcript of the table Imprisioned theater: exchanging artistic experiences in prison contexts transmitted by the YouTube platform, on $25^{\text {th }}$ May 2020, in the middle of the Coronavirus Pandemic. The table was composed by thetheater directors Christina Fornaciari, Magno Bucci, Vicente Concilio, Viviane Narvaes and Zeca Nosé and the Judge of Law, João Marcos Buch.
\end{abstract}

Keywords: Theater in prison. Criminal justice system. Human rights.

\title{
Teatro Encarcelado:
}

Intercambiando experiencias artísticas en contextos carcelarios

\section{Resumen}

Transcripción de la mesa Teatro Prisionado: intercambiando experiencias artísticas en contextos carcelarios transmitida por la plataforma YouTube el 25 de mayo de 2020, en medio de la pandemia del Coronavirus, teniendo como componentes a los directores teatrales Christina Fornaciari, Magno Bucci, Vicente Concilio, Viviane Narvaes y Zeca Nosé y el Juez de Derecho, João Marcos Buch.

Palabras clave: Teatro en prisión. Sistema penitenciario. Derechos humanos. 
A Live Teatro Aprisionado: trocando experiências artísticas em contextos carcerários foi realizada em 25 de maio de 2020, transmitida pela plataforma YouTube?. Ela ocorreu em meio à pandemia causada pelo vírus SARS-COV-2. O encontro virtual reuniu diferentes abordagens na inserção das artes cênicas em contextos carcerários, tendo em comum a busca por construir possibilidades de criação. Isso se mostra cada vez mais urgente, dada a política de superencarceramento em atividade atualmente no Brasil.

A abertura do encontro foi realizada por João Marcos Buch, Juiz de Direito da Vara de Execuções Penais da Comarca de Joinville/SC, Mestre em Hermenêutica Constitucional, Especialista em Política Criminal, formador da Escola Nacional de Formação e Aperfeiçoamento de Magistrados e escritor. Como debatedores, a mesa foi composta por:

Christina Fornaciari, Professora Adjunta da Universidade Federal de Viçosa/MG. Doutora em Artes Cênicas pela Universidade Federal da Bahia (2014). Mestra em Performance pela Queen Mary, University of London (2005) e em Teorias e Práticas Teatrais pela ECA/USP (2008). Graduada em Direito pela Faculdade Milton Campos (2002). Coordena o projeto de extensão Performance e Direitos Humanos: discursos pela tolerância.

Magno Bucci, Prof. Dr. FAAP/Ribeirão Preto e Coordenador dos grupos Mulheres de Atenas e Confraria da Serra, respectivamente na Penitenciária Feminina de Ribeirão Preto e Penitenciária de Serra Azul I.Graduado em Pedagogia pela Pontifícia Universidade Católica de São Paulo (1976). Mestre (1985) e Doutor (1994) em Artes Cênicas pela Universidade de São Paulo.

Vicente Concilio, Prof. Dr. Universidade do Estado de Santa Catarina. Licenciado, Mestre (2006) e Doutor (2013) em Artes Cênicas pela Universidade de São Paulo. Coordena o Coletivo de Teatro do Presídio Feminino de Florianópolis, que faz parte do programa de extensão Pedagogia do Teatro e Processos de Criação; e do grupo de pesquisa Infiltrações das artes cênicas nos espaços de privação de liberdade.

${ }^{7}$ Disponível em https://www.youtube.com/watch?v=v_MGCumhxnA 
Viviane Narvaes, Profa. Dra. Universidade Federal do Estado do Rio de Janeiro (UNIRIO). Doutora em Artes Cênicas pela Escola de Comunicações e Artes da USP. Coordena, em parceria com a professora Natália Ribeiro Fiche, o Programa de Extensão Cultura na Prisão.

Zeca Nosé, Professor da Universidade Federal do Amapá, Mestre em Teatro pela Universidade do Estado de Santa Catarina, Doutorando em Artes da Cena da Universidade Estadual de Campinas, onde desenvolve a pesquisa $O$ Teatro amador a partir de dois $P(S)$ : Putas e Presos.

O texto que aqui apresentamos resulta de uma transcrição feita coletivamente, pelos próprios participantes desta Live, com pequenas adaptações para o formato escrito, permitindo uma melhor fluência na leitura.

Zeca Nosé: Estamos ao vivo, gostaria de dar boas vindas a todes. Agradecer muito a presença de todo mundo, é um momento muito especial. Esta Live é um encontro de pessoas que somaram muito nas últimas duas semanas, com trocas riquíssimas durante a preparação deste encontro. É inegável que a gente vive, hoje, um momento de pandemia, perdendo muitos irmãos e irmãs. Então, eu gostaria de tirar o primeiro momento da Live para honrar as vidas dessas pessoas. Não acho que a Live sirva para a gente esquecer, mas para se fortalecer. Então eu queria desejar para todo mundo, os companheiros que estão aqui comigo e para quem está assistindo, muita força! Se unam uns com os outros. Quando a gente fala em teatro em prisão, a gente fala em duas grandes estruturas humanas: o teatro e a prisão. Pensando nisso, já introduzindo o João Marcos, optamos por convidar alguém que tivesse uma visão diferente da nossa, que somos das artes. Então a abertura é feita, com muita honra, pelo João Marcos. João, te passo a palavra.

João Marcos: Olá, boa noite a todos, muito obrigado pela lembrança e pelo convite. De certa forma é, para mim, renovador, fonte de energia, conversar com pessoas tão queridas e com uma energia tão forte, tão boa, que é própria das pessoas que trabalham com arte. O Zeca falou que gostaria, na abertura desta 
Live, de alguém que não fosse da área das artes; e realmente eu sou Juiz de Direito, da Execução Penal. Lido com leis, lido com normas, faço parte do sistema. Eu pertenço ao sistema, sou o sistema! Aquele sistema que todos vocês enfrentam no seu dia a dia, nos projetos que vocês têm. Esse sistema que vocês enfrentam sou eu! Eu gostaria de trazer para vocês esta perspectiva, de um juiz que tem essa consciência de que faz parte do sistema, e que ainda assim, entende que é possível humanizar o sistema e trazer uma redução de danos a tudo isso que o Sistema Prisional Brasileiro causa aos seres humanos: aos presos, aos familiares dos presos e à população em geral. A gente vive tempos imponderáveis de pandemia. A pandemia veio escancarar todo o calabouço escuro desses navios negreiros do século XXI. Eu vou falar um pouco com vocês sobre a violência e sobre o sistema prisional, porque aquelas pessoas que trabalham com projetos educacionais, culturais ou qualquer outro projeto perante o sistema prisional, precisam ter um conhecimento mais horizontal, ainda que genérico, a respeito de como as coisas funcionam. O trabalho de vocês pode contribuir para reduzir os danos que todo o sistema tem causado nas pessoas. No lugar do Estado brasileiro pensar e desenvolver políticas públicas com base na ciência, o que ele tem feito é menosprezá-la. Quando eu digo ciência, eu falo especialmente na criminologia, que há mais de duzentos anos já estuda o fenômeno da violência. Na década de 40, a escola de Chicago trouxe todo um arcabouço sobre as origens sociais do fenômeno da violência, do desligamento do coletivo, da fragilidade daquelas populações mais vulneráveis. Um menino nasce e cresce em um ambiente desorganizado, e da porta de sua casa vê um hotel cinco estrelas, que é um local de crianças brancas com quem ele não vai poder brincar. Ele acredita que a felicidade será ter o tênis, será ter a moto, será ter a calça de marca. Então ele parte para meios alternativos, marginais, para conquistar aquilo que ele acredita que será a felicidade, que para ele é o consumo. Não significa que a pobreza gera a violência, o que gera a violência é a riqueza, é a linha da riqueza, é o abismo econômico e social; isto que gera a violência. O Estado brasileiro, esquecendo disto tudo, em atitudes populistas que vêm desde a década de $90 \mathrm{com}$ a Lei de Crimes 
Hediondos ${ }^{8}$, fez crescer a população carcerária. Em 2006, com a Lei Antidrogas9 a mulher começou a ser encarcerada e tudo se justificativa na tentativa de superar a violência. Mas a violência não tem sido superada, porque as soluções para a violência não estão na prisão de alguém. A partir do governo Dilma, especialmente no segundo mandato, houve uma alteração desse pensamento, com o desenvolvimento de uma política de superação da cultura do encarceramento em massa, através de alternativas penais, da justiça restaurativa e de uma série de instrumentos. Porém, não deu tempo para desenvolver essas políticas, porque ela foi sacada do poder e o governo Temer paralisou todas essas políticas quando entrou. No atual governo então [Bolsonaro], tudo vai por água abaixo, a política do atual governo é super encarceradora. Inclusive com a posse do ex-juiz e atual exministro da justiça Sérgio Moro, pensei que o sistema prisional e a questão da justiça criminal teriam melhoras, mas a política de Estado dele também era encarceradora. Na realidade, o sistema prisional é o holocausto brasileiro. Eu não sou leviano quando eu falo isso, porque eu já estive em campos de concentração na Alemanha e eles me lembravam muito as prisões brasileiras. Pelos dados do Conselho Nacional de Justiça ${ }^{10}$ são mais de 840 mil pessoas presas para cerca de 400 mil vagas, quer dizer o Estado brasileiro não vai ter como construir mais vagas, não existe dinheiro para isso. A questão da superlotação gera todo o reflexo grave dos Direitos Humanos, porque os detentos vivem em ambientes super lotados, sem saneamento, sem acesso à saúde, sem acesso à educação, sem poder trabalhar, sem uma alimentação adequada, sem água corrente. Então ali são colocados aqueles jovens, que em geral tem de 18 a 28 anos, que depois disso acabam morrendo. É incrível isso! Por mês, eu julgo extintos muitos processos da execução penal em razão de óbito. E aí perguntamos: de que forma temos que trabalhar? Qual é a perspectiva de melhora deste sistema? A perspectiva de melhorar o sistema é o desencarceramento, simples assim. Não há nada que

${ }^{8}$ Lei no 8.072, de 25 de julho de 1990, que dispõe sobre os crimes hediondos, nos termos do art. 5ㅇ, inciso XLIII, da Constituição Federal, disponível em: http://www.planalto.gov.br/ccivil 03/leis/L8072.htm. Acesso em: 21 out. 2020.

9 Lei no 11.343, de 25 de agosto de 2006. Acesso em: 21 out. 2020, em: http://www.planalto.gov.br/ccivil 03/ato2004-2006/2006/lei/l11343.htm

10 Dados retirados do site do Conselho Nacional de Justiça https://www.cnj.jus.br/ Acesso em: 21 out. de 2020. 
possa ser feito de política do Estado que não seja o desencarceramento: a prisão apenas após condenadas com trânsito em julgado, e, mesmo assim, que tenham cometido crimes com violência contra a pessoa. Se nós reduzíssemos a população carcerária para um terço da atual (e ainda assim, já seria muito) talvez nós conseguíssemos trabalhar com alguma dignidade. O fato é que quando eu piso na prisão, eu ouço detento falando que teve que arrancar o próprio dente, que não tem um colchão, que não tem o cobertor... Está ali naquele ambiente superlotado, com 25 detentos, onde cabem cinco. Mulheres sem produtos de higiene. Elas me pedem - a mim como juiz - que eu aplique a lei. E eu, como parte do sistema, fico de mãos atadas. Mas o mínimo que eu posso fazer é exigir do Estado melhorias no sistema. Mas, isso não significa que eu exija a construção de cadeias. Eu exijo que a vida daquelas pessoas seja respeitada lá dentro. Nessa perspectiva, existem projetos que são importantes. A educação é fundamental dentro do cárcere, assim como o trabalho e projetos culturais. Os projetos culturais, são talvez, os de maior valor para que as muralhas que dividem o cárcere da população livre sejam rompidas. Eu sei que vocês têm muitos exemplos para me contar, mas aqui na comarca de Joinville, alguns projetos são desenvolvidos, dentre eles, a literatura no cárcere. Todo complexo prisional de mais de 2.200 presos possui a possibilidade de os presos terem acesso à relação de livros de literatura, sem censura. Temos livros de literatura clássica, popular (nacional e internacional), a obra de Graciliano Ramos, Jorge Amado, Série Vagalume, etc. E a coleção aumenta periodicamente, por meio de campanhas de arrecadação. Eles podem ler em suas celas e ao final do mês eles fazem uma breve resenha. Não é uma prova, é apenas para demonstrar que leram, e essa resenha, uma vez chancelada por professores que trabalham no sistema ou por alunos da universidade local - UNIVILLE e Projeto Proler - eu homologo essas resenhas e os detentos têm as penas abatidas. A cada livro lido por mês, são quatro dias de pena a menos. Então, por ano, são 48 dias. Os detentos começaram a ler muito, obviamente. Houve quem dissesse que teria detento que traficaria livros - já veio na cabeça o personagem traficante de livros, né: "ele fica numa pilastra lendo, lendo... e fazendo as resenhas, e vendendo as resenhas". Esse projeto chamou a atenção da editora Giostri, de São Paulo. Numa feira do livro aqui em Joinville, em que detentos autorizados por mim foram fazer 
declamação de poemas autorais, então a editora começou o projeto de oficina literária com os presos. É uma grade de horas trabalhadas, um número limitado de detentos e voluntários. Os presos aprendem a criar literatura e através disso a transformar o seu próprio eu. A editora acaba publicando esses livros a preço de custo, sem lucro algum. O último livro é: A prisão funciona? Os detentos escreveram a perspectiva deles se a cárcere funciona ou não. Outro exemplo é o livro de dramaturgia: Gritos, a dramaturgia no cárcere. Este livro já foi publicado e está circulando. Já indo para o final da minha fala (porque eu quero muito mais ouvir a todos), eu queria dizer para vocês (que trabalham com projetos de cultura nas prisões) que não desistam por causa dos percalços que acontecem. Porque eu sei que um dia os projetos de vocês funcionam bem, e no dia seguinte, quando vocês chegam vocês simplesmente não podem entrar, porque ninguém sabe quem são vocês. Não desistam, não é fácil! Tem que persistir, com muito suor, porque aí a coisa vai funcionar. Mas, tenham também a consciência de que (eu sei que todos vocês aqui tem esta consciência, e eu falo aqui para quem está nos vendo também), o protagonista dos projetos é a pessoa do preso, e que vocês são profissionais. Vocês não serão pessoas que levam e trazem recados, vocês não se envolverão emocionalmente, e vocês não estarão lá para suprir carências e necessidades suas. Estarão lá como um dever cívico. De trabalhar pela cultura, pela arte, com pessoas que estão aprisionadas. Às vezes, pessoas me procuram para fazer projetos, e eu percebo que no andar da carruagem a coisa desanda, pois não era o projeto para o outro, era um projeto para si. E isso é que nós temos que ter cuidado. Foi um grande prazer falar com vocês.

Zeca Nosé - João Marcos, agradeço muito suas palavras, foram muito potentes. Para dar sequência, eu queria passar a palavra para a Christina Fornaciari. Christina, a palavra é toda sua.

Christina Fornaciari - A fala do Dr. João realmente aqueceu meu coração. Quem dera a gente tivesse mais pessoas no judiciário com esse tipo de pensamento. Bom, neste momento, em que vivemos uma pandemia que nos impede de nos encontrar, uma série de atividades estão acontecendo on-line. Eu às vezes sinto que há um excesso e, nesse sentido, fiquei um pouco receosa sobre 
participar desse encontro porque já tem muita coisa acontecendo... Tenho lido muito o autor indígena Ailton Krenak e ele fala de que, nesse momento, há um pedido de silêncio da Terra, que esse planeta estaria pedindo para que nós, humanos, fiquemos no nosso cantinho um pouco. Mas, por outro lado, a gente que já trabalha no invisível, numa arte que é ainda mais marginalizada por acontecer no presídio, precisa deste espaço. Então vamos lá! Antes de mais nada, gostaria de abrir dizendo que estamos todos, de certa forma, experimentando a privação de liberdade. E essa restrição tem dado às artes um outro valor, ainda maior, como uma forma de manter a cabeça no lugar, de escapar para outras realidades. Então, todo mundo que está assistindo essa Live tem a capacidade de sentir na pele o que esses recuperandos sentem quando recebem uma atividade artística no presídio, quando a gente adentra o espaço deles levando um pouco de arte. Então, peço que encarem esta fala com isso em mente. Sempre gosto de iniciar qualquer exposição acerca dos meus projetos em contextos prisionais relembrando o que fala a Lei de Execução Penal11: a pena imposta ao recuperando é a perda temporária de seu direito à liberdade. Ou seja, todos os outros direitos devem ser mantidos. E o Projeto de Extensão Performance e Direitos Humanos: discursos pela tolerância tem a ver com isso. Esse pensamento é a base das nossas atividades, porque dentre os Direitos Humanos, o direito à cultura é um dos mais violados e, geralmente, quando essa violação aparece, ela também denota uma falta de outros direitos. Então, independente de a pessoa estar presa ou não, isso não deveria impedir o seu acesso à cultura. E, além disso, por meio da arte, podemos detectar outras violações que possam estar ocorrendo e, através da visibilização, buscar soluções para isso. É importante também contextualizar minha trajetória até aqui. Sou formada em Direito e, ao mesmo tempo que cursava advocacia, eu também estudava no Teatro Universitário da UFMG. Tive a oportunidade de fazer as duas formações ao mesmo tempo e isso me deu um senso social da arte muito forte, uma visão de que minha produção estética deveria ser calcada nas questões sociais e políticas do meu tempo. Isso ficou bem claro para mim quando eu visitei um presídio, no curso de Direito. Chamou minha

Lei no 7.210, de 11 de julho de 1084. Acesso em: 21 out. 2020, no site: http://www.planalto.gov.br/ccivil_03/leis/l7210.htm 
atenção a disparidade entre a lei e o que eu vi lá dentro. Eram realidades completamente diferentes. Eu percebi que a arte poderia me dar ferramentas eficazes para trabalhar essa realidade. Então, já em 2002, formada nos dois cursos e tendo experimentado trabalhos de arte comunitária, de conscientização social em favelas e aglomerados, eu decidi aprofundar minha atuação profissional para esse viés. Foi quando busquei fazer um Mestrado nesse ramo e conheci um inglês que foi o precursor de arte nos presídios brasileiros; o Professor Paul Heritage. Paul, nos anos 80, no auge da AIDS, introduziu projetos de teatro nos presídios de São Paulo e do Rio de Janeiro, como uma forma de prevenção da disseminação da doença nas prisões. Fui estudar com ele em Londres, no ano 2003. Lá fiz uma pesquisa comparativa entre os projetos de artes em presídios ingleses e brasileiros e, desde então, nunca mais parei de trabalhar com pessoas aprisionadas. Passei por experiências com menores em cumprimento de medida socioeducativa, presídios femininos e masculinos, até chegar em Viçosa, neste projeto que está em andamento atualmente (bom, não atualmente, devido à pandemia, mas que pelos últimos três anos funcionou). Trata-se de um Projeto de Extensão, fomentado pela UFV - Universidade Federal de Viçosa, onde sou professora. Então, a função dele é o vínculo entre a UFV e a cidade, e nesse sentido, entendo que os recuperandos também fazem parte da cidade. Ele é realizado na APAC Associação de Proteção e Assistência ao Condenado, em sessões semanais de oficinas com recuperandos. Ao longo desses três anos, tivemos bolsistas e participantes voluntárias, sempre mulheres, estudantes do Curso de Graduação em Dança, onde leciono. Só para contextualizar, a APAC é uma entidade civil de direito privado dedicada à reintegração social de pessoas condenadas a penas privativas de liberdade. Ela tem como objetivo a humanização das prisões e caracteriza-se por ter uma metodologia de valorização do ser humano e da sua capacidade de recuperação. A APAC oferece cursos profissionalizantes, ensino formal (lá dentro funciona uma Escola Municipal) e atividades variadas, evitando a ociosidade. Para um condenado entrar na APAC há uma série de critérios, pois abrigam, no máximo, 100 recuperandos por unidade. Então, a pessoa que está lá sabe que está em um ambiente diferenciado e, por isso, têm muito respeito pelos projetos oferecidos lá dentro - e talvez até um certo receio de regredir para o 
presídio convencional - e se engaja bastante nas atividades. Isso faz toda diferença. Nesse sentido, é um dos espaços mais privilegiados em que já trabalhei. Tudo isso permitiu que eu adotasse uma metodologia de trabalho complexa e completa, que é a Abordagem Triangular, criada nos anos 70 pela arte-educadora brasileira Ana Mae Barbosa. Nessa abordagem há três etapas para o ensino de artes: apresentação da obra, ou seja, a fruição; a contextualização da obra, ou seja, dados biográficos do artista, contexto histórico e técnica utilizada; e a execução, que seria botar a mão na massa. Essa é a nossa forma de trabalhar: apresento um artista para os recuperandos (por vídeos, fotos e livros), depois eles têm uma contextualização dessa obra e, por fim, com os meios disponíveis na APAC, a gente experimenta recriar em cima disso. Geralmente trabalhamos com fotoperformance, vivenciando a experiência performativa e registrando-a em fotografias, para futuras exposições na APAC e fora dela. Um exemplo dessa abordagem ocorreu com a obra Divisor, da Lygia Pape.

Divisor - Lygia Pape, 1968

Foto de Christina Fornaciari

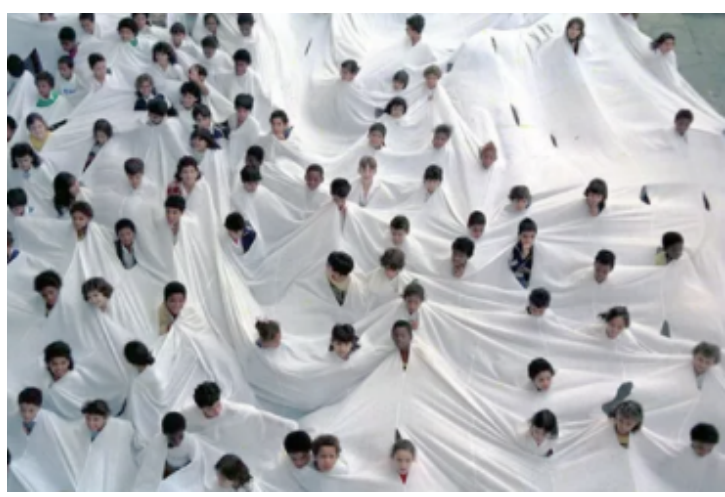

Divisor - APAC, 2018

Foto de Christina Fornaciari

Acervo da artista. Acesso em: Lygiapape.com

Em Divisor (1968), uma multidão anda pelas ruas preenchendo um pano de 30 por 30 metros, colocando a cabeça nas várias aberturas existentes. As pessoas que participaram da obra formaram um corpo coletivo, que inseriu na cidade uma onda... um mar... um movimento solto, que constrastava com o momento então vivido no Brasil: a Ditadura Militar. Assim, uma vez contextualizada e observada em fotos, partimos para a recriação desta intervenção. Levei um tecido, no qual 
realizamos furos (na APAC os recuperandos podem utilizar facas, tesouras e outros objetos cortantes, algo inconcebível para presídios convencionais). Vestimos esse tecido coletivamente e passeamos pelas dependências da APAC, numa experiência estética e lúdica, que por si já garante o estabelecimento do direito de acesso à arte. Porém, para além disso, num nível bem sutil, a obra promove um entendimento de socialização, de negociação do espaço com o outro, de diálogo para que seja possível agir coletivamente, já que é preciso coordenação entre todos para circular com esse corpo, que tem 6 cabeças, 12 pernas, 12 braços... Com essa prática, a gente está discutindo uma série de questões em torno da colaboração, da sociabilidade, da reinserção desses sujeitos em contextos de coletividade. Isso tudo, sem psicologizar, sem a necessidade de verbalizar, pois passa pelo corpo, pela vivência prática com a arte contemporânea, com a performance.

Zeca Nosé - Muito obrigado Christina, foi muito bom. Bem, eu vou passar a palavra agora para o Magno Bucci. Seja bem vindo Magno, boa noite.

Magno Bucci - Gostaria de saudar efusivamente a fala do João Marcos, uma fala que vem ao encontro do que faço há 14 anos nas duas instituições penais, Feminina de Ribeirão Preto e Masculina de Serra Azul I. Convergência de ponto de vista acerca da humanização, de uma permanência focada nos internos, na função do Estado na questão do encarceramento, na inoperância da sociedade tendencialmente punitiva, na falta de políticas públicas para a população carcerária. Em 2006 redigi um projeto - voluntário - e bati à porta da Feminina dizendo que, dentro do que sabia fazer, gostaria de colaborar com aquelas pessoas presas. O projeto foi abraçado de imediato e desde 2006 até hoje, exceto nesse momento cruel, venho semanalmente frequentado esses espaços. projeto, elaborado e assentado no acadêmico, foi descartado logo depois do primeiro encontro com as reeducandas, porque a realidade lá é bastante diversa. A visão que nós, os de fora, temos desse universo, da vida lá dentro é bem diferente. Eu tive de sair dos limites do teatro que eu apresentava como proposta, para uma atividade dentro de outros parâmetros. Para além da função estética, para função: social, pedagógica e em alguns casos até "terapêutica". Não sou 
terapeuta, mas o simples fato de ouvir, sem qualquer preconceito ou julgamento, além de relativa confiança depositada nos meus ouvidos, um certo conforto trazia para aquelas que me tomavam também como ouvinte. Essa "escuta", além da confiabilidade, aproximava do trabalho: não atrasavam, mesmos com "problemas de mente", não faltavam, incentivavam as demais, comentavam com orgulho sobre o teatro com a família, envolviam as companheiras que sabiam costurar, desenhar, etc. Eu comecei a entender um pouco daquele universo no primeiro contato com o grupo precursor. Na primeira reunião com elas, umas quinze mais ou menos, falei durante quase uma hora sobre o projeto, sobre teatro, sobre arte... e todas me olhando sem muito ar de entusiasmo. A maneira como me olhavam exigia que eu encontrasse a chave. O segredo para uma boa comunicação e aceitação. Em dado momento, tempo de uma pausa dramática, entendi o que elas estavam dizendo com as expressões: você veio aqui para ver como é e depois não voltar mais ou veio aqui para ficar e ajudar de alguma maneira? Acredito que elas estavam bastante cansadas de posarem como aquário. Encerrei o primeiro encontro com o compromisso: - vamos fazer uma experiência. Vou ficar aqui um ano, um dia por semana, tantas horas na parte da tarde. Vamos realizar alguns trabalhos a partir das sugestões de vocês, no tempo de vocês. Depois de um ano avaliamos e vocês decidem se continuo ou não. No primeiro ano do projeto, 2006, realizamos 4 montagens, em datas especiais para toda a população da instituição penal. Sobre a amplitude do teatro naquelas circunstâncias, o encarceramento, gostaria de relatar uma ocorrência na primeira montagem que fizemos na feminina. Uma menina do grupo, que não era muito assídua e só observava, uns dois dias antes da peça ser apresentada para as companheiras, me disse: professor eu quero fazer a peça. Eu, com toda expectativa da primeira montagem, incerto sobre a recepção, encarregado de todos os detalhes, com certo embaraço respondi: nós vamos estrear amanhã... está tudo pronto. Não sei como eu posso colocá-la em cena, não tem "papel" para você. Ela perguntou: - tem um vestido sobrando? Eu disse que sim. Ela continuou: - tem sapato? Colar, pulseira, brinco? Confirmei que o grupo já tinha bastante material. Ela então arrematou me ensinando o que era fazer teatro naquele território: - eu coloco o vestido, sapato alto, faço maquiagem, arrumo meu cabelo e fico andando no fim do palco. Não 
preciso falar nada, nem fazer nada, só fico andando. Sabe porque professor, olha faz 5 anos que eu não coloco um vestido; 4 anos que não sei o que é sapato alto; 6 anos que não sei o que é maquiagem. O que significa resgatar um pouco da essência do feminino. Eu não escolho quem vai compor o grupo de teatro, quem escolhe é a instituição, que tem normas, diretrizes e critérios para selecionar os participantes. Eu não sei com quem vou trabalhar. Quando começo a lista já está referendada, o aceite está dado. No caso das penitenciárias onde desenvolvo o projeto, a dinâmica não me permite adotar uma metodologia, digamos cumulativa, mais sistemática, em função da rotatividade, impedimentos, etc., inclusive com níveis de leitura diferenciados. Mas uma vez demonstrado interesse e selecionado, todos são incorporados ao grupo, sem exceção. Diante disso adoto como estratégia a improvisação. Trabalhamos com sequência, não com dramaturgia. Apreciamos mais o conteúdo vindo do grupo do que outras sugestões. Conversamos sobre muito temas: política, momento histórico, esporte, novela, liberdade, preconceito, família, mercado de trabalho, profissão, etc. Tem situações, tem assuntos que são delicados, complicados para serem abordados. Existe um idioma diferente. É preciso cuidado. Mais especificamente, o histórico desses anos demonstra que invariavelmente o assunto da encenação transita em espaço público: uma padaria, banco, indústria, praça pública etc., onde geralmente acontece um roubo e tem sempre um ex-presidiário como funcionário, que acaba sendo acusado. Imediatamente a culpa recai sobre ele. Tema recorrente porque o detento sabe do preconceito ao mesmo tempo que alimenta a luta para sair em liberdade e estabilizar a vida. Depois de todas as acusações e algumas defesas, se descobre que o patrão "esqueceu" o dinheiro em casa. Verdade restabelecida, justiça feita, pedidos de desculpas, lição de moral e reintegração. Essa é invariavelmente a sequência que se observa no grosso da produção, com poucas variações. Ao grupo, que já tinha realizado dois trabalhos e a relação amistosa era favorável, fiz uma provocação. Disse que nas peças anteriores só apareciam personagens masculinos. Era pai, filho, dono de bar, empresário, cozinheiro, bancário etc., só papéis masculinos. Como incluir um personagem feminino? Mesmo sendo teatro, esse é um dos assuntos espinhosos. A provocação - no bom sentido - foi que eu joguei o problema para eles resolverem: semana que vem 
quando eu voltar gostaria que vocês dessem a solução para incluir um papel feminino na peça. Além dos muros, a solução teatral é fácil, tendo ou não mulheres no elenco. Mas intramuros... então o que aconteceu na semana seguinte, dado que aceitaram o desafio, foi que um deles, sintetizando a criação, propôs a seguinte cena: o dono da padaria recebe um telefonema, do outro lado da linha (em off) era a esposa, que pede ao marido que leve leite, pão, manteiga e ovos para casa. O marido conversa com a mulher, anota o pedido e ainda troca palavras carinhosas ao se despedir da "patroa". Pronto. Estava inserido o personagem feminino na peça: esposa do dono da padaria - personagem oculto. O que além dos muros seria uma solução comum, corriqueira, sem arroubos criativos; intramuros, a resposta deles foi uma conquista, uma vitória, uma superação. E na esteira dessa conquista foi possível, por exemplo, encenar A paixão de Cristo, porque necessitávamos de uma personagem feminina: Maria. Um dos reeducandos se apresentou para o papel. Fez o trabalho sem caricaturar, sem falsetes, com dignidade, seriedade e responsabilidade, o que rendeu o respeito de toda população. A encenação virou um livro de fotos e depoimentos dos apenados, o que contribuiu para a migração dos nomes e feitos das páginas policiais para o caderno de cultura. Isso colabora e muito para o alcance da atividade teatral extra palco. Um esclarecimento, a escolha do texto não teve nenhum viés religioso. A peça foi escolhida objetivando contar a "história de um homem que sofreu até o limite - e morreu - debaixo da insanidade e preconceito de outros homens."

Zeca Nosé - Magno, muito obrigado por sua contribuição. Eu queria chamar agora o Vicente Concilio. Vicente, muito obrigado pela presença.

Vicente Concilio - Oi Zeca, eu que agradeço o convite de estar aqui. É uma honra mesmo estar ao lado de pessoas muito especiais. A Vivi eu conheço, a gente já tem uma parceria antiga, mas conhecer a Chris, o Magno e ouvir mais uma vez o juiz João Marcos é sempre bom. Ele já participou de alguns eventos aqui na Udesc, o Seminário Internacional de Arte com a Educação Prisional, que foi desenvolvido aqui em uma parceria do Centro de Artes e a Faculdade de Educação, a FAED, logo que a Udesc começou a implantar o vestibular nos presídios. A gente uniu forças de dois programas de extensão e construiu esse grande evento que 
aconteceu em 2017 e foi a partir desse evento que eu consegui acessar o presídio feminino de Florianópolis, que é onde a gente agora desenvolve nossa ação prática de Teatro numa unidade de regime fechado. Eu contei todo esse preâmbulo porque na verdade eu comecei a fazer Teatro em presídios em 2001, quando eu morava em São Paulo, uma experiência realizada com outros profissionais lá no Presídio Feminino do Tatuapé. Era um programa encabeçado pelo diretor de teatro Jorge Spínola, que hoje mora na Bahia, e esse trabalho acabou resultando na minha pesquisa de mestrado. A gente trabalhou dois anos no presídio feminino do Tatuapé. Depois, outros dois anos com pessoas no regime semiaberto e egressos do sistema. Este processo resultou no espetáculo Muros. Esse grupo acabou virando um coletivo teatral de pessoas que já tinham cumprido pena, e durou até 2007. Eu acabei vindo para Florianópolis e demorei até conseguir acessar o "sistema" aqui em Floripa. Só foi possível graças ao evento que mencionei antes, porque até então eu havia tentado negociar com a direção das unidades; uma coisa é eu ter esse acordo, outra coisa foi o momento em que a Secretaria de Justiça e Cidadania viu que a gente realmente tinha interesse como Universidade em desenvolver um trabalho a longo prazo. Eu considero que a grande importância do Teatro nas Prisões, para além de realmente mudar as pessoas, como mudou a minha vida, é quando a gente consegue promover o encontro dos artistas que estão em situação de cárcere com o público. Essas pessoas conseguem então se sensibilizar, conseguem perceber que elas não estão diante de presidiários e presidiárias, mas que elas estão na verdade diante de artistas. Para mim, esse momento da troca é fundamental para mudar esse imaginário que está construído, arraigado na nossa mídia de que a prisão é esse lugar cheio de animais e de pessoas brutalizadas, que não perdem uma oportunidade para atacar fogo nos colchões e produzir as maiores barbaridades (como se essas barbaridades, quando elas acontecem, também não fossem uma consequência da situação a que essas pessoas estão sujeitas). Desde o segundo semestre de 2017, estamos lá no presídio feminino de Florianópolis. Participam do trabalho bolsistas de pesquisa e estagiários e estagiárias, minhas orientandas de mestrado. São pessoas que acompanham, realizam análises, produzem artigos para sistematizar essa prática. No ano que passou, a gente conseguiu construir um espetáculo com a dramaturgia 
da Caroline Vettori que se chamou: Estendemos Nossas Memórias ao Sol. Esse espetáculo foi convidado para participar do principal festival de Teatro da cidade de Florianópolis. A gente conseguiu o apoio da direção da unidade, que batalhou junto ao juiz para que liberassem as atrizes para se apresentarem em um teatro fora da unidade, e isso é um marco: você imaginar que um grupo de pessoas cumprindo pena de privação de liberdade conseguiu participar como atrizes dentro do maior festival da cidade! Foram muito importantes as repercussões dessa apresentação: o encontro das atrizes com seus familiares (que puderam assistir), mais o encontro com as pessoas da sociedade civil (que ficaram sabendo e conseguiram ingresso), as pessoas que não conseguiram assistir (mas souberam do que estava acontecendo e perceberam importância do projeto). A gente retomou o trabalho depois do carnaval, mas aí veio a pandemia e tudo parou. A gente tinha então dobrado o número de pessoas interessadas em participar do nosso projeto. Também a partir do segundo semestre do ano passado, a gente conseguiu entrar no sistema de medida socioeducativa, Centro de Internação Feminina, o CIF - Florianópolis. Basicamente essas eram as ações. Nós estávamos tentando ampliar, porque é um interesse dos nossos alunos aqui no curso de Artes Cênicas, buscar formas de atuação como docentes para além da escola. Uma ação que eu acho importante (e essa conversa está dentro dessas ações), é tentar reunir todas essas iniciativas que envolvem as Artes Cênicas nos espaços de privação de liberdade, principalmente aquelas que são vinculadas às Universidades Federais ou Estaduais do Brasil. Avante!

Zeca Nosé - Obrigado Vicente por compartilhar sua experiência com a gente. O interessante que está se mostrando aqui é que são experiências de lugares diferentes, com abordagens bem diversas. Passo agora a fala para a Viviane Narvaes. Muito obrigado pela presença Viviane.

Viviane Narvaes - Boa noite a todes que estão nos assistindo. É uma alegria e uma honra enorme estar aqui conversando com esse grupo e trocando nossas experiências. Não dá para começar a falar sobre o projeto antes de pensar o momento social que a gente está vivendo. Uma situação de uma crise sanitária nunca vista, que afeta, mata e adoece uma parcela muito significativa da 
população, mas uma parcela que tem classe e raça definidas. Essa mesma parcela da população que sofre com a política de encarceramento em massa em curso no nosso país. Majoritariamente, as pessoas que estão em situação prisional nesse momento pertencem às classes populares e são negras e negros. Embora muitas ações de desencarceramento estão sendo tomadas por setores do judiciário e por pessoas como o João, que falou aqui com a gente, a maior parte da população carcerária está sofrendo dentro das prisões. Aliás é um prazer ouvir um Juiz da Vara de Execuções Penais falar com toda essa potência. A gente está em um momento sem nenhum contato externo, nenhum contato com familiares. Então, ao mesmo tempo que é uma alegria estar com vocês aqui, estamos todos com o coração muito apertado, angustiados com o que está acontecendo atrás dos portões de ferro das penitenciárias. Eu faço parte do projeto de extensão Teatro na Prisão: Uma experiência pedagógica em busca do sujeito cidadão. Esse projeto já tem 23 anos e a fundadora do projeto está ali no chat, assistindo a gente, é a professora Natália Ribeiro Fiche. Então, estou na maior responsabilidade aqui. Quando eu entrei para dar aulas na Unirio, no meu primeiro dia, "sempre conto essa história", eu estava pegando o elevador com a minha carta de apresentação para ir para a direção da escola e Natália me puxou assim: Oi, há quanto tempo! O que você está fazendo aqui? Eu disse: Eu estou vindo tomar posse. Ela então disse: - Você vai entrar comigo para o projeto! E daí já faz 11 anos que eu estou aprendendo com ela e com todas as pessoas encarceradas que fazem parte. 0 projeto da Natália de teatro nas prisões, já incluía, na época que eu entrei, um trabalho junto com uma professora da biblioteconomia. A Natália buscava relações sempre com vários professores da nossa instituição, tentando fazer abordagens interdisciplinares. Alguns anos depois que eu entrei, dois ou três, a gente conseguiu formatar essas experiências interdisciplinares que já aconteciam em um programa de extensão que se chama Cultura na Prisão e tem vários professores envolvidos, com diversas atividades nas unidades prisionais. A principal continua sendo o projeto de teatro na prisão que hoje se desdobrou em um outro projeto específico que é Artetransformando LGBTQUIA+ encarcerdxs, que é uma outra faceta do Teatro na Prisão, com uma turma específica para essas pessoas presas. O programa engloba também o projeto O leitor como protagonista, que é um 
trabalho de dramaturgia e de escrita criativa. Mais do que só dramaturgia, ele reúne egressos do sistema prisional e pessoas que estão cumprindo o regime semiaberto, coordenado pelo professor Marcelo Santos. Elas vão para a Unirio e têm encontros com esse professor, trabalhando os processos de escrita criativa. A gente participou também na Unirio da articulação de um grupo de professores e estudantes para fazer o projeto de remissão pela leitura. Hoje, a gente está fazendo o teatro...quer dizer... hoje não estamos fazendo, né? Hoje estamos pensando em quando e como e com quem vamos voltar a fazer o Teatro nas Prisões. Mas estamos fazendo uma nova ação diante do contexto da pandemia, chama-se Sinal de vida: correspondência solidária. Estamos enviando cartas nossas, da equipe de estudantes que trabalha conosco, para as pessoas que estão encarceradas. Cartas que têm o objetivo de dizer que estamos aqui fora preocupados e querendo saber o que eles demandam da gente. O que podemos fazer? Cartas que também pretendem fazer a manutenção de um vínculo afetivo e profissional com as pessoas encarceradas, e artístico, evidentemente. A gente trabalha com várias propostas, mandamos poemas, no caso da unidade maternoinfantil, exercícios de respiração e uma série de propostas que os ajudem a passar por esse momento, que além de todas as mazelas do encarceramento, é um momento de muita solidão. Difícil imaginar essa solidão em meio à superlotação do sistema prisional, mas é a solidão da falta do contato com as famílias, ou mesmo com os entes externos, as escolas que estão paralisadas principalmente aqui no Rio de Janeiro. Bom... O Vicente jogou uma bola para mim eu vou pegar aqui. A gente, eu acho que em 2011 - Natália, me corrija se eu estiver errada estabeleceu uma parceria com a Universidade de Michigan, onde há um projeto até mais antigo do que o Teatro na Prisão, um projeto que tem quase 30 anos. Conhecemos a professora Ashley Lucas, e de 2011 para cá, a gente tem realizado residências artísticas integradas. A gente vai para lá, os professores e estudantes da Unirio e da Udesc, experimentamos o processo, a metodologia e visitamos algumas unidades prisionais. A Ashley vem para cá, para o Rio de Janeiro e para Santa Catarina com um grupo de estudantes da Universidade de Michigan e a gente faz essa troca, buscando aperfeiçoar nossas metodologias. Para concluir essa fala inicial, sobre a metodologia, eu concordo muito com o que o Magno falou. 
A gente não tem receita de bolo, cada estudante nosso, porque o trabalho nas prisões também serve como experiência de estágio não formal, para nossos estudantes. Então cada grupo de estudantes que vai atuar nas prisões, vai conhecer um grupo de pessoas encarceradas e desenvolver com elas uma metodologia conforme os interesses daquele grupo. A gente já fez Teatro do Oprimido, já fez com ações físicas, coisas mais improvisacionais e variadas técnicas de acordo com os interesses de quem está fazendo a oficina naquele ano ou semestre, de acordo com os estudantes que estão conduzindo. Agora, a gente tem uma série de procedimentos que esses 23 anos de existência nos ensinaram. São regras estabelecidas por nós com os estudantes da Unirio, de condutas que precisam ser tomadas para tentar garantir que a gente consiga entrar nas prisões e permanecer. Esses procedimentos incidem em alguns aspectos da criação artística, porque o sujeito que está ministrando a oficina fica com a conduta um pouco diferenciada, não como uma oficina de teatro aqui fora, mas o teatro é uma potência monumental dentro do cárcere, porque naquelas poucas horinhas que a gente está ali dentro se experimenta um estado de liberdade, ainda que transitório. Permite ao sujeito se reconhecer de outra forma naquele mundo, nas relações. Então vou passar de volta a palavra aos colegas.

Zeca Nosé - Eu estava vendo aqui o chat e tem a Anne Martins, companheira lá do Amazonas, com um projeto lindo chamado Arbitrio. Tem também o Emerson de Paula meu colega na Universidade Federal do Amapá, ele também tem um projeto dentro dos presídios. É bacana tanta gente participando desse encontro. Eu queria falar muito rapidamente como surgiu a Live. Eu estou fazendo um levantamento para a minha tese. Eu pesquiso prostitutas que fazem teatro em Belém do Pará e as experiências do Magno Bucci em Ribeirão Preto. Comecei a fazer um levantamento de diversas experiências de teatro na prisão, por isto contatei algumas pessoas para a pesquisa. Desses contatos surgiu a ideia desse encontro muito bonito! Eu queria falar sobre a importância cultural dos eventos teatrais que envolvem amadores, seja na prisão, seja com prostitutas, pode ser na escola também. A gente tem uma tendência de diminuir esses eventos como se eles fossem de segunda classe. Tem uma pesquisadora da UNIRIO, a Luciana Pena, 
que fez uma dissertação linda sobre a importância cultural no teatro amador no começo do século passado, no Rio de Janeiro; e ela demonstra de uma maneira brilhante o quanto o teatro dito amador era importante, tanto quanto o profissional. Por isto, eu assumo a nomenclatura amador para me referir a todos esses eventos teatrais que pesquiso. Eu estava na no presídio com o Magno, fui assistir à estreia do espetáculo dele e tinha um dos presos (ele estava sentado na frente), e ele se emocionou muito com o espetáculo, mas não podia chorar (ao menos foi a leitura que eu fiz) e eu tenho a impressão de ter visto ele engolindo o choro. Então, o teatro feito por amadores tem uma importância cultural única, que o teatro profissional não alcança. É o preso assistindo os companheiros [outros presos] em cena. O que ele sentiu dificilmente um outro tipo de espetáculo traria para ele. Eu entendi essa função estética diferenciada quando vi a minha filha em cena pela primeira vez. A minha filha foi participar de uma festa junina da escola, ela entrava com uma bandeirinha e eu comecei a chorar, fiquei muito emocionado, e me perguntei: por que que eu estava emocionado vendo uma performance muito simples? Porque a vinculação com minha filha ocorria de forma única. Nenhum outro ator poderia me dar aquela emoção. A Viola Spolin fala que todo público tende a ser justo com os atores, menos se este público for composto de parentes e amigos. O teatro feito por atores amadores tem como uma de suas características que exista a proximidade entre o espectador o ator. Também é comum que os espectadores e os atores troquem de lugar. Vendo as apresentações do Magno, ficava evidente esta dinâmica, porque no dia seguinte da estreia do espetáculo, tinha uma lista de 40 nomes querendo entrar no grupo. Como os espectadores se sentem íntimos dos atores, eles têm vontade de ir para a cena também. Eu trabalhei muitos anos dentro da escola com teatro, e esta dinâmica é perceptível lá. Antes de você estrear o espetáculo, às vezes, os alunos têm ressalvas pela exposição - mas uma vez que o espetáculo é feito - ele se torna um chamariz para novos alunos. Então eu queria colocar este ponto: a importância cultural do teatro praticado por amadores, seja na prisão, seja no prostíbulo ou na escola. Ele ocupa um lugar que nenhuma outra prática pode ocupar. 
Bom, vou trazer todos de volta para a nossa mesa de discussão. A Anne pergunta como se dão as relações de gênero e de poder dentro das prisões?

Christina Fornaciari - Em relação a gênero, há uma postura de respeito muito grande dos recuperandos em relação a mim e às bolsistas. Todas as integrantes do projeto são mulheres, e o trabalho desenvolve-se em uma APAC masculina. Isso poderia indicar possíveis problemas de gênero, no entanto, a gente nunca sentiu nenhuma forma de assédio ou menosprezo por sermos mulheres e eles, homens. Porém, a própria APAC possui todo um sistema de funcionamento da entrada de terceiros, em que até o nosso vestuário é modificado. Por exemplo, uma coisa que parece não fazer sentido - mas depois a gente percebe que faz é que necessário vestir um jaleco branco por cima das roupas convencionais, e, no caso de mulheres, essas roupas por baixo do jaleco não podem ser justas. Isso dá a impressão de querer esconder as curvas e formas do corpo feminino. Também não se pode entrar com sapato aberto, apenas bota ou sapato fechado. Isso se dá por motivo de segurança, pois existem as oficinas de marcenaria nas quais algum visitante poderia se machucar. Porém, no caso de mulheres, a coordenadora da APAC uma vez mencionou para nós que o sapato fechado impediria questões ligadas a fetiches por pés, unhas pintadas e coisas do tipo. Via de regra, essas medidas são gerais, aplicadas para qualquer visitante, homem ou mulher, incluindo professores, familiares, etc. Mas o principal fator nessa questão de gênero vem da própria relação de confiança que se estabelece no fazer artístico. Retomando a ideia do espelho, tão bem colocada pelo filósofo Michel Foucault, de que o sujeito precisa do outro para entender a si próprio. O outro é sempre o meu espelho, eu sei quem eu sou, a partir do olhar do outro, de como esse outro se dirige a mim. Nesse sentido, penso que esse espelho que os recuperandos encontram em nós, integrantes do projeto, reflete uma imagem bonita de volta para eles, que é o modo como nós os vemos. Talvez por essa razão, nos sentimos tão seguras em trabalhar lá. Além do mais, a relação de confiança que se estabelece em razão da natureza dos trabalhos, é bem diversa das relações de poder que podem haver com os professores da escola formal, os psicólogos, etc. E, pelo fato de a APAC não ter a figura do agente penitenciário, já que 
o próprio recuperando é quem cuida de toda a estrutura de funcionamento da casa, de um modo geral trata-se de um ambiente bastante tranquilo, as relações interpessoais são muito mais horizontalizadas. O que existe de fato é uma troca: a gente entra para oferecer uma oportunidade de experiência artística e eles oferecem para gente um espaço para perceber a arte de uma outra forma, democratizar essa experiência artística e fazer um laço social entre as comunidades intra e extra muros carcerários. Lembrando que, como todo Projeto de Extensão, devemos fazer a ponte entre a universidade e a comunidade, porém raramente se pensa nos recuperandos como parte disso. Nesse sentido, o projeto atinge as pessoas que mais estão separadas de um convívio comunitário, ou seja, as que mais precisam ser alcançadas pela atividade extensionista.

Magno Bucci - É justamente isso que a Christina falou. Gostaria de citar um fato. Quando chego para o trabalho, sempre peço licença para entrar, porque estou entrando na casa deles. Quando chego na masculina, estendo a mão para todos, chamo pelos nomes, nunca pelo apelido. Já na feminina, quase a mesma coisa: cumprimento coletivo e sempre acompanhado de uma agente. Porque é uma coisa da instituição, esse cuidado. Na feminina tem um regramento diferenciado. Outra coisa, as meninas sofrem mais com relação às visitas. O homem quando vai preso, geralmente tem a mãe, a parceira, as filhas visitando. Quando a mulher vai presa, pelo menos o que tenho ouvido delas, é que a família praticamente abandona.

Viviane Narvaes - Como eu falei naquela fala de apresentação, a gente nesse momento, Annie, está desenvolvendo um projeto justamente voltado para a questão LGBTQIA+. A sociedade sofre com o machismo, com racismo, com a LGBTQIFobia e, evidentemente isso acontece dentro das unidades prisionais também. Elas não estão fora a sociedade, né? Tem muita gente que usa o termo "ressocializar", eu gosto sempre de frisar que ele não é um termo tão adequado, porque que a prisão é estrutural, como instituição da nossa sociedade. Essas questões são difíceis de se tratar lá dentro, como são difíceis aqui fora para nós mulheres, para as mulheres negras mais difícil, para a comunidade LGBTQUIA+ também. A gente tem alguns procedimentos, como eu falei antes, vestimenta, 
forma de cumprimentar... esses procedimentos não se dão por causa das pessoas encarceradas, eles se dão para que a gente consiga passar da porta de entrada da prisão. A gente vai com camiseta, uma camiseta da Unirio, a gente pede que não se use aqueles sutiãs com aros, que não bote brinco, anel, pulseira, relógio... por quê? Uma época a gente falava assim: "a gente tem que ir para lá e ficar feio, bem feio mesmo", não é para aparecer a nossa sexualidade, mas não era exatamente isso... a questão é que quando você vai com os seus acessórios, com a sua roupa, já na porta de entrada, sofre o machismo, o racismo e LGBTQlfobia. Ao entrar, você passa por todo o sistema de segurança, e os acessórios, não passam no detector de metal, você já perde tempo. Se você está cheio de coisas, vai às vezes perder meia hora de trabalho, porque eles vão ficar fazendo você ir e voltar no detector e até tirar tudo, até pegar tudo de volta, até colocar.... As situações mais ímpares que eu já passei em termos de relações de poder com as opressões, se dão normalmente no momento da entrada na unidade prisional. Nós tivemos uma situação de um aluno o negro que sempre sofria muitas piadinhas por conta do estilo dele, eles achavam que podiam fazer aquele tipo de piada, mas não faziam com nenhum outro estudante. São situações difíceis, e a gente lida com elas na medida que acontecem. Por parte das pessoas encarceradas, há muito respeito. Evidentemente, há sim tentativas de aproximação, escrevem cartas, cartas amorosas normalmente, porque se desenvolve afeto. Mas é curioso que muitas vezes, essas cartas, não tem nem o nosso nome. Elas foram escritas para uma mulher, uma pessoa imaginária ou uma pessoa que ele pudesse acessar e entregar aquele gesto de afeto, de amor. Não é necessariamente direcionado àquela professora de teatro que está indo lá sempre. Mas eu acho que como os movimentos sociais, os movimentos de luta contra as opressões, estão ganhando força na sociedade, isso acaba se refletindo, de uma forma ainda muito pequena, dentro das unidades. Agora tem situações em que já se aceita o tratamento pelo nome social das pessoas, não é em todas as unidades, mas em algumas já se aceita. Quando eu comecei a entrar na prisão, se eu chamasse alguém pelo nome social, a guarda chegava e reprimia na hora: "não pode, tem que chamar ele ou ela pelo nome de registro". Vou contar para vocês uma coisa muito linda (acho que o teatro permite ressignificar essas coisas). Uma vez a gente estava num grupo de 
mulheres e tinham muitos homens trans no grupo. A gente estava fazendo um jogo com objetos, todo mundo de olhos fechados tocando no objeto, fazia uma ação com aquele objeto e passava para outra pessoa. Eu tinha levado uma série de objetos que não estão no cotidiano delas, batom, sabonetinhos, hidratantes, coisinhas assim... Em um dado momento, estávamos em roda, o Carlão passou o batom na boca. No momento que ele passou na boca, abriu os olhos e falou: Ih! Virei mona! e todas as outras abriram os olhos, riram e o jogo acabou. Mais tarde (porque ele já estava sendo solto), encontrei com Carla novamente, ela estava com os filhos dela no metrô. Eu não sou da psicologia, não sei sobre a subjetividade dele/dela ${ }^{12}$, mas assumiu um papel de gênero lá dentro (e, me desculpem se eu não estou usando a expressão mais correta, porque esse não é um debate que domino) que seria o lugar que mais oprime. Talvez lá ela/e tenha conseguido ser quem ela/e realmente era. Do lado de fora, teve que voltar ao papel de mãe e mulher de alguém... não dá para saber, eu acho que tudo isso é muito relativo, que existe o machismo e as demais opressões dentro do sistema, mas também existe a força dos movimentos sociais que estão impactando, tanto na realidade das pessoas livres, quanto na realidade das pessoas encarceradas.

Vicente Concilio - Eu sempre trabalhei principalmente em unidades femininas, e eu sendo um homem gay, acho que nunca houve muita tensão com relação à forma com que eu me relacionava com elas. Então, tanto em São Paulo, quanto hoje em Florianópolis, a gente tem uma relação de contato físico, de abraços, dentro dos limites do trabalho que a gente quer desenvolver. Mas, a gente teve um problema justamente quando fomos trabalhar no socioeducativo masculino. O bolsista sofreu preconceito, por ser um homem gay. Os agentes começaram a acusar ou apontar... digamos... a " viadagem" nos meninos que estavam fazendo a aula, por estarem entrando no jogo junto com o professor. Então, acabou acontecendo uma série de situações que minou o trabalho e a gente decidiu sair de lá. A gente não tinha um apoio tão forte como aquele que a gente teve, por exemplo, no Presídio Feminino. Com relação a gênero, cada lugar tem as

${ }^{12}$ Talvez o mais adequado aqui fosse utilizar o "x" ou "u" para grafar, pois para além do que eu disse na Live, há possibilidade da pessoa ter uma identidade de gênero não binária. 
suas nuances, as suas sutilezas. Com relação ao poder, é diferente. A gente está sempre entre esse lugar do agente e o lugar das pessoas que estão cumprindo pena. A gente não quer ser visto pelos presos como alguém do corpo funcional da unidade e, ao mesmo tempo, os agentes ficam o tempo inteiro nos patrulhando para que a gente não tome atitudes muito diferentes, e que nos coloquem muito ao lado das pessoas que estão cumprindo pena. Então, essa é uma nuance muito delicada. A gente acaba não querendo desrespeitar a regra da unidade, como a Christina acabou de falar sobre ter que vestir um jaleco. Tomar uma atitude heróica, tipo falar assim: Ah, eu não admito usar isso, você ouviria: Tchau, vai embora. Não põe mais o pé aqui. E o que você ganhou com isso? Nada. Porque o trabalho deixa de acontecer e as pessoas, que são justamente com quem a gente quer desenvolver o trabalho, perdem essa oportunidade. É um aprendizado muito grande para a gente, como coordenador, aprender a engolir essas coisas, mirando o trabalho que a gente quer desenvolver.

Zeca Nosé - A gente tinha mais dois temas para tratar, mas eu acredito pela hora, que caminhamos para o final e temos que marcar logo uma segunda Live. Foi muito importante tudo que foi dito. Eu vou passar 30 segundo para cada um trazer as últimas palavras.

Viviane Narvaes - Vou fazer a propaganda aqui do nosso projeto, sigam a genteláno Instagram@fuga.coletiv@é um grupo de estudantes e ex-estudantes da Unirio, que trabalhou com a gente nas prisões. Tem também um dos integrantes que está em regime semiaberto, o Edson, que está ali nos assistindo. Nós criamos criou um coletivo teatral e estamos agora fazendo criações em quarentena, fizemos um espetáculo bonito que eu não sei quando vocês vão poder ver, acho que quando tudo isso acabar. Procura a gente também @teatro.prisão é o Instagram do nosso programa de extensão; e eu queria agradecer mais uma vez por estar aqui, eu queria falar um milhão de coisas.. Eu vi ali que tem mais perguntas no chat, depois quando acabar a Live respondo, tentando responder ou trocar contatos com vocês. Gente valeu! Muito obrigada e vamos fazer outras com certeza porque é muita coisa para perguntar para os colegas e não deu tempo. 
Christina Fornaciari - Para finalizar, também vou fazer o meu merchan: o meu instagram é @chris_fornaciari e meu e-mail é christinafornaciari@gmail.com. Me escrevam que eu envio, com o maior prazer, artigos e minha dissertação de mestrado a quem se interessar. Agradeço mais uma vez pelo convite para esta conversa tão animadora. Bom saber que não estou sozinha, esse tipo de iniciativa nas micropolíticas me fortalece demais.

Magno Bucci - São importantes esses encontros para a conscientização, iluminar a cabeça das pessoas de que esse mundo prisional não está distante da nossa realidade, está a um passo e é preciso ter um outro olhar, outra visão para minimizar aquilo que o João Marcos mencionou, a falta de políticas públicas. Se eles não fazem, vamos fazer nós.

Vicente Concilio - Christina, Magno, Zeca, Vivi. Eu acho que foi muito incrível, foi muito importante, enquanto eu ouvia, estar acompanhando ali e a galera debatendo no chat da transmissão, vendo que, sim, dá para ter uma Live com a Anne, dá para chamar o Emerson, dá para chamar a Natália, dá para falar com a Samira, lá de Joinville. A gente também pode estar lá como espectadores, porque a gente tem muito o que ouvir, já que a gente ainda não está podendo organizar uma grande conferência. Agora eu já tenho esse sonho, que a gente tem que se encontrar para fazer uma reunião, pode ser aqui em Floripa, a gente já traz o João Marcos que é daqui do lado, a gente já faz um "fuzuê" por aqui para poder ver, se encontrar, se abraçar. Enfim, o que o Mário falou é real, a gente está lidando com esse momento da pandemia, eu fico muito preocupado com as minhas alunas que estão lá, pois a gente não tem acesso, nem carta a gente pode mandar porque eles não podem receber, porque pode estar contaminado, só pode receber e-mail. Assim, tudo está num lugar muito louco, mas é isso, vamos torcer para que não entre nenhum vírus lá. O que me conforta é imaginar que isso é uma medida para que ninguém seja contaminado. Enfim, foi um calor aqui nesse momento gélido que a gente vive e fora Bolsonaro e, por favor, vamos batalhar pelo abolicionismo penal ou, pelo menos, para que a gente reduza esse punitivismo estrutural em nossa sociedade. 


\section{Urdimento}

Zeca Nosé - Eu queria agradecer a todos, eu estou completamente apaixonado por todos vocês. Obrigado a todos e muita força para todo mundo aí!

Recebido em: 21/10/2020

Aprovado em: 22/10/2020 